\title{
ANKYLOSING SPONDYLITIS IN SISTERS
}

\author{
BY \\ THOMAS N. FRASER \\ From the Gardiner Institute of Medicine, University of Glasgow, \\ and the Western Infirmary, Glasgow
}

The incidence of ankylosing spondylitis appears to be on the increase and during the recent war a large number of cases was observed among the forces. Boland and Present (1945) reported that 18 per cent. of soldiers admitted to a U.S. Army General Hospital with chronic back complaints were found to have this disease. Graham and Ogryzlo (1947) also noted in the Toronto Arthritis Centre the high ratio of one case of ankylosing spondylitis to every $2 \cdot 8$ cases of rheumatoid arthritis. This apparent increase in the incidence of the disease is undoubtedly due, in part, to quicker diagnosis, with the result that many cases which have not advanced beyond a very early stage are now being recognized.

Ankylosing spondylitis is predominantly a disease of young men. Buckley (1931) reported a sex incidence of ten males to one female. This is the average figure given, although Graham and Ogryzlo (1947) reported a ratio of 16 to 1 and Bauer (1939) 20 to 1 respectively in their series. On the other hand, Fletcher (1944) found that 47 per cent. of 68 patients with the disease were females, a finding which he was unable to explain. The sex incidence in my own series was three males to one female.

Evidence is available, though by no means conclusive, to support the view that ankylosing spondylitis is a familial disease (Stecher and Hauser, 1946; Campbell, 1947; Rogoff and Freyberg, 1949) and its occurrence in brothers has been reported from time to time. Ray (1932) recorded the disease in twin brothers; Stecher and Hauser (1946) also described two brothers and cited three other instances of the disease affecting brothers. Campbell (1947) stated that in his series of 25 cases two of his patients were identical male twins, another two were brothers, a fifth had a brother who had died from the disease, and a sixth had an uncle and a brother with the disease. Tegner and Lloyd (1949) noted that all three children of one family (two brothers and a sister) were suffering from ankylosing spondylitis.

The occurrence of ankylosing spondylitis in sisters, however, is so rare that the presentation of the following is thought to be justified. I have noticed only one report in the literature of the disease affecting sisters (Scott, 1942), but no details are given. This rarity of " sister " cases might, of course, reasonably be explained by the low incidence of the disease in females. 


\section{Case Histories}

The family history is as follows. The patients' father, mother, two brothers, and two sisters are alive and well. The mother had rheumatic fever at the age of 28 , and one brother and one sister show evidence of old healed rickets. The members of the family as a whole are of short stature.

Case 1.-Single, aged 31, clerk. Previous health: chickenpox, measles, whoopingcough, and rickets, as a child.

History.-The first symptom of ankylosing spondylitis appeared in 1936, when at the age of eighteen she noticed that her lumbar spine was stiff but not painful. The stiffness disappeared without treatment after six weeks, but returned a year later and has been present since. About this time her doctor accidentally discovered that she had an endocarditis. Shortly afterwards she developed a dull ache in the lumbar region. From then on the disease slowly progressed to involve the sacro-iliac joints, the dorsal and cervical vertebrae, the shoulders, hips, and temporo-mandibular joints. No history of iritis. During the course of the disease she received various forms of treatment, including bedrest, deep $x$-ray therapy, physiotherapy, and spinal supports. At present she complains of a slight ache in the lumbar spine, and stiffness in the spine as a whole, and in the shoulders, hips, and jaws.

Present Condition.-Height $4 \mathrm{ft} .7$ in., weight 6 st. 2 lb., E.S.R. (Westergren) 44 $\mathrm{mm}$. Standing erect the patient shows dorsal kyphosis, forward inclination of the cervical spine, slight hyper-extension of the head, flattening of the lumbar spine, shortening of the femora, and anterior bowing of both tibiae. The head is slightly tilted to the right and movement of it is impossible, the cervical spine being immobile. The lower jaw has receded because of involvement of the temporo-mandibular joints and its range of movement is limited to 1 in. There is slight limitation of movement at the shoulder and elbow joints. All movements of the hip joints are considerably restricted, especially abduction which is limited to $30^{\circ}$. There is tenderness on pressure over the ischial tuberosities. Chest expansion is 1 in. All the other joints, including those of the hands, appear to be unaffected. Systolic and presystolic murmurs at the mitral area are heard and confirmed by phonocardiogram. Blood chemistry-serum calcium $10 \mathrm{mg}$. per $100 \mathrm{ml}$.; inorganic phosphate $4.5 \mathrm{mg}$. per $100 \mathrm{ml}$.; alkaline phosphatase 8 units (Kay).

Radiological Findings.-The appearances are those of advanced ankylosing spondylitis involving the whole of the spine (Fig. 1) with extreme osteoporosis of the vertebral bodies, complete obliteration of the sacro-iliac joints and the apophyseal joints, and calcification in the anterior common ligament and in the ligaments and capsules of the facet joints. Erosion of bone is seen in the pubic rami, ischial tuberosities, the greater and lesser trochanters and the 6th and 7th cervical spinous processes. Narrowing of joint space is seen in the shoulder, hip, and temporo-mandibular joints. There is evidence of old rickets of the femora, tibiae and fibulae.

Case 2.-Single, aged 29, clerk. Previous health: measles as a child.

History.-The earliest symptom of ankylosing spondylitis appeared in 1939, when at the age of 19 she developed pain down the back of both legs. This cleared up completely after bed-rest for six weeks. About a year later she noticed a stiffness in her neck, shoulders, and lower back, and this was accompanied by girdle pains. The disease slowly spread and in 1943 her neck became very painful. In 1945 the finger joints began to be painful and swollen and she experienced considerable pain in both hips, especially the right, and the temporo-mandibular joints. No history of iritis. During the course of the illness she received bed-rest, several courses of deep $x$-ray therapy and physiotherapy, injections of myocrisin, and spinal supports. At present she complains of pain 


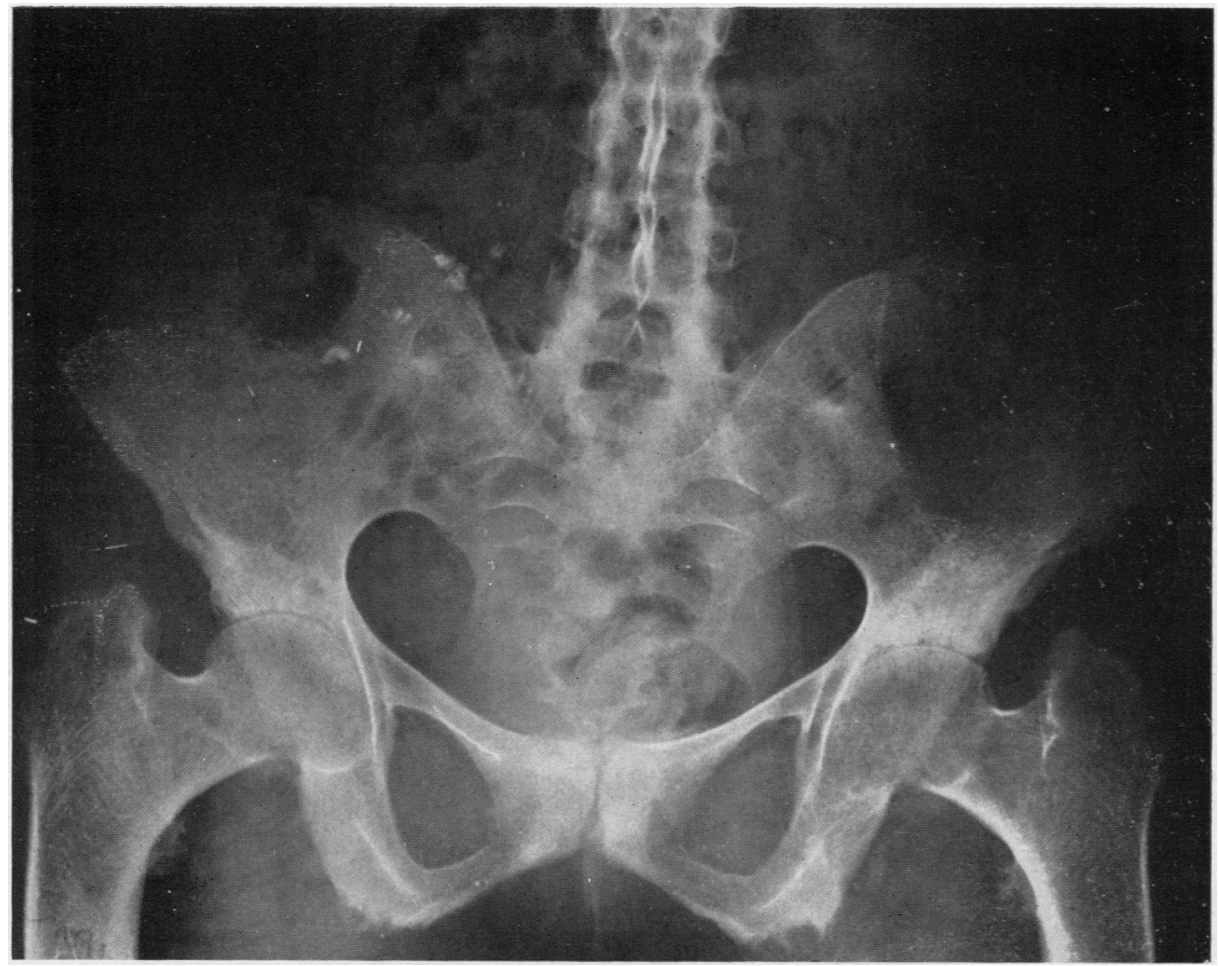

FIG. 1.-Case 1, showing advanced degree of ankylosing spondylitis. Note (a) sclerosis in iliac bones, and $(b)$ erosions of bone at ischial tuberosities, and greater and lesser trochanters.

in both hip joints, particularly in the right, and stiffness of the neck, lower back, and fingers.

Present Condition.-Height $4 \mathrm{ft} .11$ in., weight 7 st. 3 lb., E.S.R. (Westergren) 18 $\mathrm{mm}$. Standing erect the patient shows moderate kyphosis of the dorsal spine, forward inclination of the cervical spine, and slight hyperextension of the head. The normal lumbar lordosis is still present. All head movements are considerably restricted. There is some pain in the temporo-mandibular joints on opening the mouth to its full extent, but the jaw movements are full. A little swelling of the proximal interphalangeal joints of the index and middle fingers of both hands and a moderate degree of interosseal wasting is present. There is tenderness on pressure over the ischial tuberosities and the greater trochanter on both sides. The hip movements are full, but accompanied by some pain on abduction. Chest expansion is limited to $\frac{1}{2}$ in. All the other joints appear to be intact. A basal systolic murmur is present. Blood chemistry-serum calcium $10.4 \mathrm{mg}$. per $100 \mathrm{ml}$.; inorganic phosphate $3.9 \mathrm{mg}$. per $100 \mathrm{ml}$.; alkaline phosphatase 5 units (Kay).

Radiological Findings.-The appearances are those of a moderately advanced ankylosing spondylitis. There is complete obliteration of both sacro-iliac joints and involvement of the apophyseal joints of the lumbar, dorsal, and cervical vertebrae(Fig. 2, overleaf). Calcification of the anterior common ligament in the cervical spine and of the lateral ligaments in the lower lumbar region is present. Irregularity of the symphysis pubis, the ischial tuberosities, and both greater trochanters is seen. $X$ ray of the hands shows some soft-tissue swelling of the fingers, and decalcification of the phalanges and metacarpal 


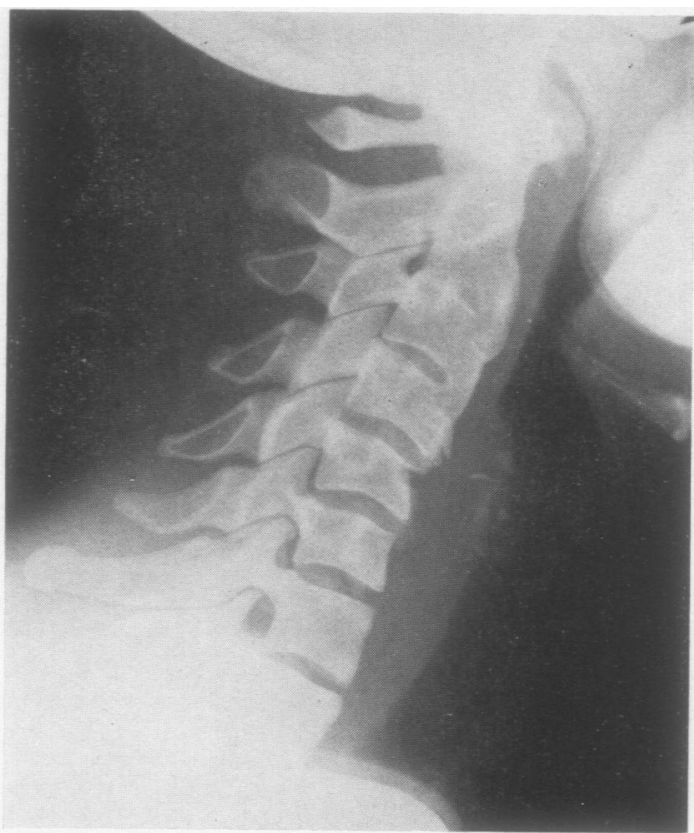

FIG. 2.-Case 2, showing involvement of cervical spine.

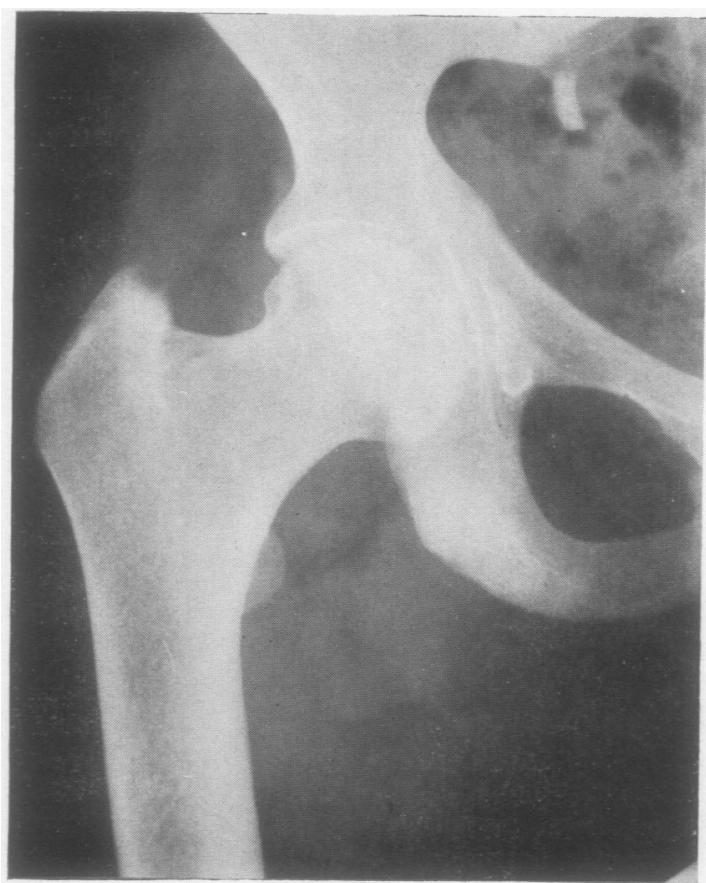

Fig. 3.-Case 2, showing (a) erosion of greater trochanter, and $(b)$ calcification in gluteus minimus. bones, but no loss of joint space. There are no radiological changes in the temporo-mandibular, shoulder, or hip joints. Calcification in the attachment of the gluteus minimus to the greater trochanter on the right side can be seen (Fig. 3).

\section{Discussion}

Although ankylosing spondylitis may not uncommonly affect two or more members of the same family, e.g. two brothers or a brother and sister, its occurrence in two sisters is of sufficient rarity to be worthy of recording.

Both patients present some interesting features. Case 1 , the subject of advanced ankylosing spondylitis, shows evidence of old healed rickets. The occurrence of the two diseases in the same patient is thought to be fortuitous, more particularly as there is a family history of rickets. In passing, I would like to record that I have seen another woman with a similar and more advanced combination of ankylosing spondylitis and old rickets.

Case 1 has well-marked mitral stenosis. It is not possible to establish whether this lesion has the same underlying aetiology as ankylosing spondylitis or whether it has been the result of a previous mild attack of rheumatic fever which has been overlooked. Hart and others (1949) found that the erythrocyte sedimentation rate was raised in the majority of their patients with ankylosing spondylitis, but 
did not consider that the test was of much value in assessing the response to therapy. The findings in Case 1 tend to support this view, as the erythrocyte sedimentation rate has remained consistently high $(40-50 \mathrm{~mm}$.) in spite of obvious clinical and radiological improvement in the patient's condition. This patient also shows evidence of disease in the peripheral joints, especially the hip, shoulder, and temporomandibular joints. The latter have been extensively involved. Clinically there is recession of the lower jaw with marked limitation of movements of the mouth, while $x$ ray reveals considerable loss of joint space. Erosion of bone at muscle attachment, which, according to some observers (McWhirter, 1945; Mowbray and others, 1949), differs in no way from the early subarticular erosions in the sacroiliac joints, has been noted in ankylosing spondylitis. These lesions are present in Case 1 (Fig. 1) and affect notably the pubic rami, ischial tuberosities, the greater and lesser trochanters, and the lower cervical spinous processes.

The first symptom noted in Case 2 was pain down the back of both legs. Buckley (1945) laid great stress on the presence of sciatic pains as being among the earliest symptoms in ankylosing spondylitis, and showed that they may be present for as long as a year before there is any complaint referable to the sacroiliac joints or spine, a point which cannot be stressed too often. Like her sister, this patient has evidence of peripheral joint involvement, affecting mainly the temporo-mandibular joints, the hips, and the hands. There is painful swelling of the proximal interphalangeal joints of the index and middle fingers, and a moderate degree of interosseal wasting, the appearances being clinically indistinguishable from rheumatoid arthritis. $X$ ray of the hands shows soft-tissue swelling of the involved finger joints, and decalcification of the phalanges and metacarpal bones, but no loss of joint space. Case 2 also shows erosion of bone at muscle attachments, particularly at the right greater trochanter (Fig. 3), where calcification in the gluteus minimus has occurred. This osteoblastic invasion of muscle has been reported from time to time (Mowbray and others, 1949).

Finally, both patients complained of discomfort in the buttocks on sitting for any length of time and experienced considerable pain when pressure was applied over the ischial tuberosities. This is a not uncommon finding, but one that is liable to be overlooked.

\section{Summary}

(1) A brief review of the literature on the familial incidence of ankylosing spondylitis is given.

(2) Case records of two sisters with ankylosing spondylitis are presented. One of them is also the subject of old rickets.

(3) Some interesting features of the disease are brought out by a study of these patients.

\section{REFERENCES}

Bauer, W. (1939). New' Engl. J. Med., 221, 524.

Boland, E. W., and Present, A. J. (1945). J. Amer. med. Ass., 129, 843.

Buckley, C. W. (1931). Brit. med. J., 1, 1108.

- (1945). Annals of the Rheumatic Diseases, 5, 49.

Campbell, A. M. G. (1947). Lancet, 1, 406. 
Fletcher, E. (1944). Ibid., 1, 754.

Graham, W., and Ogryzlo, M. A. (1947). J. Canad. med. Ass., 57, 16.

Hart, F. D., Robinson, K. C., Allchin, F. M., and Maclagan, N. F. (1949). Quart. J. Med., $18,217$.

McWhirter, R. (1945). Brit. J. Radiol., 18, 302.

Mowbray, R., Latner, A. L., and Middlemiss, J. H. (1949). Quart. J. Med., 18, 187.

Ray, M. B. (1932). Proc. R. Soc. Med., 25, 325.

Rogoff, B., and Freyberg, R. H. (1949). Annals of the Rheumatic Diseases, 8, 139.

Scott, S. G. (1942). "Adolescent Spondylitis or Ankylosing Spondylitis." Oxford Univ. Press, London.

Stecher, R. M., and Hauser, H. (1946). Amer. J. Roentgenol., 56, 601.

Tegner, W., and Lloyd, K. (1949). Lancet, 2, 196.

\section{Spondylite Ankylosante chez des Soeurs}

\section{RÉSUMÉ}

(1) On passe brèvement en revue la littérature sur l'incidence familiale de la spondylite ankylosante.

(2) On présente l'histoire clinique de deux soeurs atteintes de spondylite ankylosante. Une d'elles avait des antécédents de rachitisme.

(3) L'étude de ces malades met en évidence quelques caractères intéressants de la maladie.

\section{Espondilitis Enquilosante en Hermanas}

\section{RESUMEN}

(1) Reseñamos brevemente la literatura sobre la incidencia familiar de la espondilitis enquilosante.

(2) Señalamos la historia clínica de dos hermanas sufriendo de esta enfermedad. Una de ellas presentaba, además, síntomas de antiguo raquitismo.

(3) El estudio de estas enfermas pone en relieve algunos rasgos interesantes de esta enfermedad. 